\title{
Making Our Judgments Right: Ethics of Corporal Punishment in Indian Schools
}

\author{
Ashwini Tiwari ${ }^{1}$ \\ ${ }^{1}$ Department of curriculum and Instruction, College of Education, The University of Texas-Pan Am, Edinburg, \\ TX, USA \\ Correspondence: Ashwini Tiwari, Department of Curriculum and Instruction, The University of Texas-Pan Am, \\ 1201 W. University Drive, EDCC 2.642, Edinburg, TX 78539, USA. Tel: 1-956-665-8769. E-mail: \\ tiwaria@utpa.edu
}

Received: November 30, 2014 Accepted: January 6, 2015 Online Published: April 27, 2015

doi:10.5539/ies.v8n5p69

URL: http://dx.doi.org/10.5539/ies.v8n5p69

\begin{abstract}
The case Ayub Khan v. Municipal Corporation of Delhi Schools is one of the landmark cases for promoting a conversation on ethics of corporal punishment in Indian society. Based on literature synthesis and the critical examination of the Court case using ethical frameworks (Stefkovich, 2006; Stefkovich \& Shapiro, 2010) this paper argues that law alone may not preclude teachers from using an age old practice such as corporal punishment. Furthermore using literature related to the Court case as secondary data sources, the paper argues that teachers trained in incorporating ethical paradigms in their decision making presents best chances for effective implementation of laws against corporal punishment in Indian schools.
\end{abstract}

Keywords: corporal punishment, physical punishment, ethics, India, law

\section{Introduction-Ethics in Teaching Profession}

Ethics is concerned with judgment people make regarding right or wrong based on morality (Stob, 1978). People use their consciousness based on their background and past experience to solve problems in ethical manner. Ethical framework is basic assumptions about beliefs, values and principles to guide choices (Starratt, 2004). An ethical framework constantly guides individuals to make decisions. There are four main ethical frameworks: ethics of justice, ethics of care, ethics of critique and ethics of profession (Starratt, 2004; Stefkovich, 2006; Stefkovich \& Shapiro, 2010). Depending on the situation one or more than one ethical framework could be applied to solve problems. Stefkovich (2006) argues that due to the nature of profession teachers often use more than one framework to conduct their daily business (See Table 1).

Ethical frameworks help educators adopt unique perspective where they go beyond the rulebook of schools to make the best judgments for the students. Knowledge of ethical frameworks provides teachers with a lens to evaluate their decisions based not only on legal framework but also on ethics. Teachers trained to use ethics in their daily businesses tend to be more sensitive towards students' need (Begley \& Stefkovich, 2004; Begley \& Stefkovich, 2007). These teachers use ethical perspectives to solve students' related matter in fair and just ways leading to promotion of equality and equity.

In western countries such as United States, teacher preparation programs started incorporating ethics in their curriculum from early on. There is a long line of literature on ethics in teaching profession in United States. Scholars such as Dewey (1909) talked about ethics in teaching in his book Moral Principals in Education. He argues that ethical decision making requires educators to use critical reflections before choosing an action over other, which is usually informed by societal values.

While teachers in the United States learn about ethics through teacher preparation curriculums, teachers in countries such as India have a fewer opportunities to get trained in ethics while undergoing teacher preparation programs. Additionally, ethics in Indian teacher preparation programs is primarily adopted from the western countries (Tiwari, 2013). Therefore, applying ethical frameworks originated in western countries could provide insights on ethical implications of school corporal punishment in India and could demonstrate the necessity of ethical training for educators. 
Table 1. Ethical paradigms at a glance

\begin{tabular}{ll}
\hline Ethical Paradigms & Description \\
\hline Ethics of Justice & Ethics of justice focuses on fair treatment of all persons and it urges educators to look \\
& to laws and public policies for ethical guidelines (Strike et.al, 2005; Furman 2004). An \\
& educator operating under ethics of justice paradigm evaluate the school policies \\
& keeping in mind the rights of the students and the school community.
\end{tabular}

Ethics of Care

Ethics of care prompts educators to make moral decisions and requires educators to use multiple voices in decision-making process (Shapiro \& Stefkovich, 2010). According to Gilligan (1982) interconnectedness between need, sensitivity and peaceful conflict resolutions are core feature of care.

Ethics of Critique Ethics of critique aims at awakening educators to inequalities in society to lead them to development of options related to authority, voice, empowerment and privilege (Shapiro \& Stefkovich, 2010). Questions related to rules and their enforcement could be asked through ethics of critique

Ethics of Profession Ethics of profession is a dynamic process that requires development of personnel and professional codes to make judgments and decisions (Shapiro \& Stefkovich, 2010). Educators have responsibilities towards teaching profession and thus society at large.

\section{Method}

The Court case: Ayub Khan v. Delhi Municipal Corporation Schools, 2009

Shanno Khan-an 11 year old girl with learning difficulties from an elementary school ran by the Municipal Corporation of Delhi (MCD) - was asked by her teacher to memorize English alphabet as homework. The next day as a consequence for Shanno's inability to recite the alphabet, the teacher spanked Shanno and gave her a time-out outside the classroom (Samson, 2009). Later, Shanno fainted and became unconscious. Shanno was rushed to the hospital where she slipped into a comma and passed away on April 17, 2009. Shanno's parents lodged a police complaint against the teacher and later went to the Delhi High Court. The Delhi the Commission for Protection of Child Rights has been investigating the case on the directives of the Court. The final verdict on the case is still pending.

\subsection{Overview of Corporal Punishment in Indian Schools}

Corporal punishment has been widely practiced in India to discipline students for centuries. Teachers use corporal punishment to teach students to behave appropriately or perform high academically (Chiang \& Shouse, 2011; Tiwari, 2014). According to Hindu mythology teachers are equated to god. In the ancient system of schooling, Gurukul, the students were sent to live with their teachers at a very young age. The parents usually relinquished their parental rights, turning over care of their children to the teachers. Additionally, parents gave rights to the teachers to discipline their children as required (Raj, 2011). Gradually the teachers gained a powerful status among the parents of Gurukul system of education. Although, the Gurukul system of education no longer exists, the belief that education could only be earned with hardships under strict teachers' discipline still persists in the Indian society.

Furthermore, wide acceptance of corporal punishment in Indian schools is reminiscent of colonial schooling system. The master-servant relationship, which characterized the socio-political oppression of colonial rule, was institutionalized in the schools and persists today (Raj, 2011). A majority of teachers in Indian public schools are from upper caste and discriminate toward students from lower caste (UNICEF, 2007). Different political parties use schools to promote their own agenda based on division of caste and language.

The political propaganda started in colonial India publicized that people who knew English were superior to those who did not know English is still widespread in Indian schools. Students are punished for their inability to converse in English. Students face corporal punishment in many cases because they could not converse with teachers in English.

According to a study done by National Council for Protection of Child Rights (NCPCR, 2011), 69\% of the students attending Indian public school face corporal punishment. The report found that those students who come from minorities or low socio-economic status are more vulnerable to corporal punishment in schools. 
Some of the commonest methods of corporal punishment are caning, spanking, slapping, physical discomfort to the body and discomfort caused by inappropriate body posture.

However, in last couple of decades, injuries or death of the students due to corporal punishment in schools has made this practice controversial. In 2000, the Supreme Court of India ruled that corporal punishment should be outlawed from the schools (Bhowmick, 2009). Almost after a decade, in 2009-the same year Shanno died-the government of India banned corporal punishment in schools through Right to Education Act (RTE). However, even with the judicial and legislative ban, the practice still continues (NCPCR, 2011).

\subsection{Why Ethical Frameworks to Analyze the Case?}

Ethical framework guides an individual's values and beliefs related to right and wrong (Starratt, 2004). Employing ethical framework to the case on corporal punishment approaches issues through a way of thinking where jurisdiction is both legal and ethical. Additionally, it bridges the gap between social and educational conversations related to corporal punishment. Corporal punishment was made illegal at the time of the incident. However, clearly the law was ignored which is indicative of the fact the law alone could not bring change. Critics (e.g., Stefkovich, 2006; Walker, 1998) argued that conversations based on ethical frameworks present the best chance for a safe learning environment.

Shapiro and Stefkovich (2010) proposed that in educational settings multiple ethical paradigms should be used to solve issues related to students. Stefkovich (2006) stated that the best interest of students could be fulfilled only when educators approach problems with more than one ethical frameworks. In her book, Best interest of the student: Applying ethical constructs to legal cases on education, she mentions that multiple ethical frameworks have an overarching theme, which could help school stakeholders understand and solve complex problems (See Figure 1).

\section{Results and Discussion}

Analysis of Ayub Khan v. MCD based on ethical frameworks

Ethics of justice, as it applied to the case, showed that the teacher treated Shanno unfairly in that she could have given Shanno extra time to learn English alphabet. Teachers have certain rights to enforce the homework polices. However, the social construct where ethics of justice originated clearly states that individuals have to give up certain rights for the good of society (Starratt, 1994, as cited in Stefkovich, 2006, p. 9). The teacher allowing Shanno to recite the alphabet at a later day could have depicted that she trusts her students, which is an essential foundation for effective teaching and learning.

As Stefkovich (2006) states, role of individual in relation to others take into account mutual expectation, trust, loyalty and concern (p. 10). The teacher has known the family for quite some time. The parents had been sending their three children to the school on a regular basis, which indicates that they were committed to the education of their children. Therefore, one could argue that the teacher could have called the parents to talk about Shanno's inability to recite alphabets.

One of the components of the ethics of care requires educators to include multiple voices in decision-making process to come to a conclusion (Stefkovich, 2006). The teacher decided to act with her own discretion by not involving any member of the family or school community showed her insensitivity towards the public school system, which is based on democratic values. The teacher could have asked herself: Is the student going to benefit from the action? Would she be hurt from the action? How would corporal punishment help the student? Is it going to help the society? The teacher's answers to these questions could have prompt her to take actions in accordance with the ethics of care. 


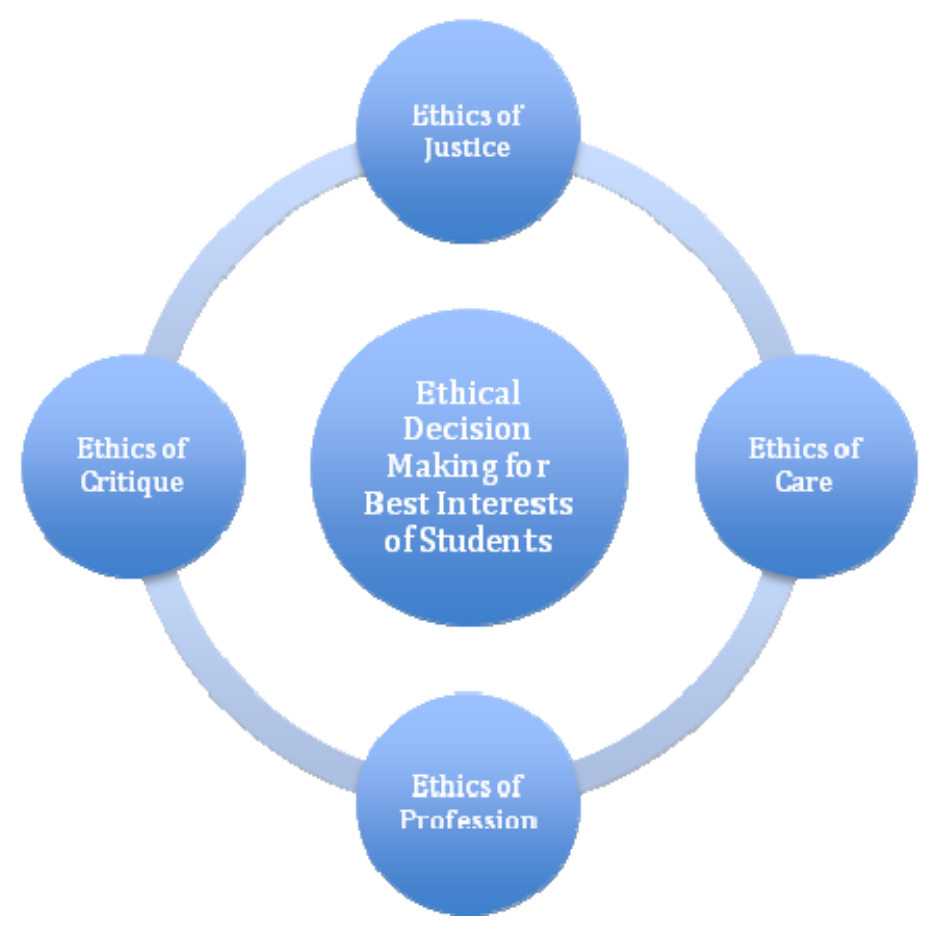

Figure 1. Ethical decision making in K-12 school settings

Ethics of care as it concerns the teacher shows that the teacher has showed little compassion towards Shanno. Shanno spent two hours in sun and repeatedly request for water (Bhowmick, 2009; Times News Network, 2009). However, she was not given permission to drink water. As Stefkovich (2006) quoted Nodding, "ethics of care assumes that human beings have intrinsic worth and emphasizes unconditional commitment to others". Perhaps, the teacher's refusal to allow Shanno to get water could lead students to believe that they were insignificant.

Applying the ethics of critique to the role of Municipal Corporation of Delhi (MCD) school board indicated that MCD has defended its status quo that a MCD employee could not harm a student. The MCD has maintained that teacher is not the cause of Shanno's death. They have said that the teacher used spanking and time-out to discipline the student but never neglected her. I is not clear if the school has a written guideline on student discipline. However, it is unlikely that they had a code of conduct or school discipline handbook (Tiwari, 2013). In such case how do they determine consequences of the student's misbehaviors?

Looking at the case with ethics of critique raised a question if the teacher has violated human rights by asking a student to stand in the sun and denying her to get water (Times News Network, 2009). One may argue that the teacher, who came from Majority Hindu religion, discriminated Shanno, who came from minority Muslim religion. Historically, students from lower caste and poor religious background have faced more corporal punishment in Indian public schools (UNICEF, 2009).

The critical theorist would ask who has made the rules and who is responsible for enforcing them (Stefkovich, 2006). It is not known from the secondary court documents if the school Shanno attended has a homework policy and if the teachers are required to enforce it. However, considering the fact that it a public school in Delhi, it is unlikely they have a written homework policy. If this is the case, then Shanno's request to give her another chance was clearly ignored. The critical theorist would argue that the use of the homework rule favors individual teachers. Teaching profession urge that teachers to understand their learners and context of the rule to make a decision to bring the positive changes (Dewey, 1909).

Ethics of profession as it applied to the case asked what the profession would expect of the teacher. Dewey (1909) argued that role of schools are to prepare students for the future. It is expected that teacher adopt a teaching style that brings the best in the students. Shapiro and Stefkovich (2010) suggested that the teacher, in addition to professional ethics, follow their personal codes of ethics build on personal values and experiences. The idea is that teachers' ethical values resonate with the moral aspects of teaching taking into considerations all attributing factors that affect the students (Furman, 2004). 
Shanno was 11 years old, she attended second grade; she had learning issues (Samson, 2009; Times News Network, 2009; Tiwari, 2013). When a student face challenges with academic subject area, it becomes necessary for the teacher to seek intervention. Different modalities of learning help student who lag behind in academics (Shah et. al., 2014). However, in Shanno's case the teacher has adhered to a rigid curriculum, and followed stereotypic teaching methods. Asking children to recite alphabet letters may work with some students whereas, other students learn alphabets through different methods such as stories.

Teachers have a moral obligation to pay attention to the unique needs of the students (Shah et al., 2014; Starratt, 1994; Strike et al., 2005). Children's needs could be educational, psychological and familial. When applying ethics of profession teachers start to see if students have problems learning the subject and if they have an issue with schools, or the family problems are letting the student lag behind in the academics (Stefkovich, 2006).

\section{Conclusion}

Schools would not be able to provide opportunity for a safe learning environment to all students until teacher preparation programs in India incorporate ethics of corporal punishment in their curriculum. The ethical-moral dimension in the teacher preparation curriculum would convey principles of right and wrong, mutual respect to human beings, the manner in which a person should conduct oneself and value stands that guide such conduct (Greenfield, 1993; Begley \& Stefkovich, 2004; Begley \& Stefkovich, 2007; Stefkovich \& Shapiro, 2010; Tiwari, 2014). The teaching profession requires teachers to take into consideration all attributing factors that affect students; only then we can take right decisions in the best interest of students. Legislations such as Indian RTE Act, which prohibits corporal punishment in schools, combined with guidelines to promote teaching based on ethical and moral principles presents the best chances for safe learning environment.

India is a collective society where individual interests are outweighed by community interest. It is a general tendency among Indian parents to accept corporal punishment as a right provided to schools to educate their children. Therefore, it is imperative that teachers learn about ethics of corporal punishment to make their decision in the best interest of students (Raj, 2011; Tiwari, 2013). Despite the ban corporal punishment has not been eliminated from Indian schools, which indicates that law alone is not enough. There is a need to begin a conversation based on ethics of corporal punishment.

The teachers are authorities in the classrooms and thus it's their moral obligation to act ethically and rationally with respect for the rights of students. Based on literature synthesis of secondary data this paper conforms thatteachers who have received training in ethics are more likely to teach students about their rights, duties and responsibilities (Shapiro, \& Stefkovich, 2010; Stefkovich, 2006; Starratt, 1994; Tiwari, 2014). It is likely that empowering the students by making them aware about their rights could make a difference in their educational process and create safe learning environments.

\section{References}

Begley, P. T., \& Stefkovich, J. (2007). Integrating values and ethics into post secondary teaching for leadership development: Principles, concepts, and strategies. Journal of Educational Administration, 45(4), 398-412.

Begley, P. T., \& Stefkovich, J. A. (2004). Introduction: Education, ethics, and the "cult of efficiency": Implications for values and leadership. Journal of Educational Administration, 42(2), 132-136.

Bhowmick, N. (2009, May 2). Why India's Teachers Do Not Spare the Rod. Time. Retrieved from http://www.time.com/time/world/article/0,8599,1895495,00.html

Chiang, Y. C., \& Shouse, R. C. (2011). Taiwan's Ban on Corporal punishment: Teachers' perceptions of impact and meaning. International Journal for Educational Reform, 20(2), 111-131.

Dewey, J. (1909). Moral principles in education. Boston: Houghton Mifflin.

Furman, G. C. (2004). The ethic of community. Journal of educational administration, 42(2), 215-235.

Greenfield, W. D. (1993). Articulating values and ethics in administrator preparation. Educational administration in a pluralistic society, 267-287.

National commission for protection of child rights (NCPCR). (2011). Eliminating corporal punishments in schools. Retrieved from http://ncpcr.gov.in/index 1.php?lang=1\&level=1\&\&sublinkid=113\&lid=300

Raj, L. (2011). Understanding corporal punishment in India. Career Educator: An Interdisciplinary Education Journal, 1(1), 3-18.

Samson, M. (2009). Under the Shadow of Shannon's Death. Economic and Political Weekly, 13-15.

Shah, R., Das, A., Desai, I., \& Tiwari, A. (2014). Teachers' concerns about inclusive education in Ahmedabad, 
India. Journal of Research in Special Educational Needs. http://dx.doi.org/10.1111/1471-3802.12054

Shapiro, J. P., \& Stefkovich, J. A. (2010). Ethical leadership \& decision making in education. New York: Routledge.

Starratt, R. J. (1994). Building on ethical school. London: Falmer Press.

Stefkovich, J. A. (2006). Best Interests of the student: Applying legal ethical constructs to legal cases in education. New York: Routledge.

Stob, H. (1978). Ethical Reflections. Grand Rapids, MI: Eerdmanns.

Strike, K. A., Haller, E. J., \& Soltis, J. F. (2005). The Ethics of School Administration (3 ${ }^{\text {rd }}$ ed.). New York: Teachers College Press.

Times News Network. (2009, April 18). Delhi girl in coma after school punishment Dies. Retrieved from http://timesofindia.indiatimes.com/city/delhi/Delhi-girl-in-coma-after-school-punishment-dies/articleshow/ 4413949.cms

Tiwari, A. (2013, March 10). Corporal punishment in cross-cultural context: Applying ethical paradigms to a court case from India and United States. Paper presented at the annual meeting of the $57^{\text {th }}$ Annual Conference of the Comparative and International Education Society, Hilton Riverside Hotel, New Orleans, LA. Retrieved September 15, 2014, from http://citation.allacademic.com/meta/p633285_index.html

Tiwari, A. (2014, June 24). Teachers, discipline and the corporal punishment ban in Delhi, India (Unpublished doctoral dissertation). The Pennsylvania State University, University Park, United States.

UNICEF. (2007). All you want to know about corporal punishment. Retrieved from http://www.unicef.org/india/reallives_5449.htm

Walker, K. (1998). Jurisprudential and Ethical Perspectives on "The Best Interests of Children". Interchange, 29(3), 287-308.

\section{Copyrights}

Copyright for this article is retained by the author(s), with first publication rights granted to the journal.

This is an open-access article distributed under the terms and conditions of the Creative Commons Attribution license (http://creativecommons.org/licenses/by/3.0/). 